\title{
Study of Temperature Dependence of the Deposition Rates of Ni-P Based Sonication-Assisted Nanoscale Electroless Composite Plating
}

\author{
Hengzhi ZHOU ${ }^{1,2}$ *, Yuqiang GU ${ }^{1}$, Wenhao WANG ${ }^{1}$, Rui LIU ${ }^{1}$, Yuqiang BAI ${ }^{1,2}$, \\ Baosen ZHANG ${ }^{1,2}$, Xiangyang MAO ${ }^{1,2}$
}

\author{
${ }^{1}$ Department of Material Engineering, Nanjing Institute of Technology, Nanjing, Jiangsu, 211167, People’s Republic of \\ China \\ ${ }^{2}$ Jiangsu Key Laboratory of Advanced Structural Materials and Application Technology, Nanjing, Jiangsu, 211167, \\ People's Republic of China
}

crossref http://dx.doi.org/10.5755/j01.ms.24.4.19128

Received 27 September 2017; accepted 25 December 2017

\begin{abstract}
In this study, $\mathrm{SiCp} / \mathrm{Ni}-\mathrm{P}$ nano-composite coatings were fabricated on 45 steel substrates under ultrasonic excitation at temperatures from $85^{\circ} \mathrm{C}$ to $45^{\circ} \mathrm{C}$. The micro-morphologies and compositions of the coatings were analyzed using Scanning Electron Microscopy (SEM) and Energy Dispersion Spectrum (EDS). The deposition rates of the different processes were then investigated using the polarization curve method, the weighing method, and the film thickness method. The effects of sonication on the coating process were also investigated. The results reveal that free energy decreased to $16.38 \mathrm{~kJ} / \mathrm{mol}$, which can be attributed to the positive effect of sonication on the reaction activity. Furthermore, the deposition rates of the composite plating decreased with the process temperature. Specifically, the deposition rates measured by the polarization curve method, weighing method, and film thickness method decreased from $0.625 \mathrm{mg} /\left(\mathrm{cm}^{2} \cdot \mathrm{h}\right)$ to $0.116 \mathrm{mg} /\left(\mathrm{cm}^{2} \cdot \mathrm{h}\right)$, from $3.9 \mathrm{mg} /\left(\mathrm{cm}^{2} \cdot \mathrm{h}\right)$ to $1.6 \mathrm{mg} /\left(\mathrm{cm}^{2} \cdot \mathrm{h}\right)$, and from $36.64 \mu \mathrm{m} / \mathrm{h}$ to $7.05 \mu \mathrm{m} / \mathrm{h}$, respectively.
\end{abstract}

Keywords: sonication-assisted, electroless composite plating, nano-SiC, deposition rates.

\section{INTRODUCTION}

Nanoscale electroless composite coatings containing nanoparticles such as $\mathrm{SiC}[1], \mathrm{A}_{2} \mathrm{O}_{3}[2]$, and carbon nanotubes [3] exhibit superior hardness and durability compared with conventional coatings. For this reason, they have been widely applied in the nuclear, aerospace, and transportation industries [4]. However, conventional electroless composite plating has limited applications because of the high coating temperatures and low deposition rates involved in the process. To mitigate these issues, techniques such as sonication have been incorporated into electroless composite coating [5-10], and several studies have reported using sonication-assisted methods to fabricate composite coatings that have excellent performances $[5,6,11-13]$. Previous studies introduced sonication from the bottom, such that the level of energy reaching the deposition interface was relatively low [14]. In contrast, this study focused on immersion-type sonication-assisted nanoscale electroless composition plating on 45 steel substrates. The $\mathrm{SiC} / \mathrm{Ni}-\mathrm{P}$ nano-composite coatings were prepared using different techniques and under different temperatures. The morphology and chemical composition of the coatings, as well as the deposition rates, were then investigated to understand the effects of sonication on the plating process.

\section{EXPERIMENTAL}

\subsection{Sample preparation}

First, 45 steel substrates $(25 \mathrm{~mm} \times 10 \mathrm{~mm})$ were polished and treated chemically through immersion in $5 \mathrm{~mL} / \mathrm{L}$ basic $\mathrm{HCl}$ solution in order to activate the surface. Then, $100 \mathrm{~mL}$ of plating solution (formula shown in Table 1) was prepared.

Table 1. Solution formula for electroless composition plating

\begin{tabular}{|c|c|}
\hline Component & Content, g/L \\
\hline $\mathrm{NiSO}_{4} \cdot 6 \mathrm{H}_{2} \mathrm{O}$ & 25 \\
\hline $\mathrm{C}_{6} \mathrm{H}_{5} \mathrm{Na}_{3} \mathrm{O}_{7} \cdot \mathrm{H}_{2} \mathrm{O}$ & 15 \\
\hline $\mathrm{CH}_{3} \mathrm{COONa}_{3} \cdot 3 \mathrm{H}_{2} \mathrm{O}$ & 18 \\
\hline $\mathrm{NaH}_{2} \mathrm{PO}_{2} \cdot \mathrm{H}_{2} \mathrm{O}$ & 30 \\
\hline $\mathrm{SiC}$ & 5 \\
\hline
\end{tabular}

After the samples were immersed in a 1:1 $\mathrm{HCl}$ solution and rinsed thoroughly using deionized water, $\mathrm{SiC}$ (diameter $20 \mathrm{~nm}$ ) was added into the plating solution. Immediately afterwards, the mixed plating solutions were sonicated for $5 \mathrm{~min}$ and pre-heated to the plating temperature. Different steel substrate samples were immersed when the temperature reached $85^{\circ} \mathrm{C}, 75^{\circ} \mathrm{C}, 65^{\circ} \mathrm{C}, 55^{\circ} \mathrm{C}$, and $45^{\circ} \mathrm{C}$. At the same time, sonication was introduced, and deposition gradually occurred. The power, frequency, and working period of sonication were $1500 \mathrm{~W}, 90 \mathrm{kHz}$, and $1 \mathrm{~h}$, respectively. After deposition, the samples were all rinsed with deionized water. Compared with the bottom-

\footnotetext{
${ }^{*}$ Corresponding author. Tel.: +086-13813831077.

E-mail address: zhzmsc@njit.edu.cn (H.Z.Zhou)
} 
introduction method, the method that uses ultrasonic waves has the advantage of higher transmission efficiency. It is also easy to control, because the immersed ultrasonic horn that initiates the waves can be placed very close to the deposition interface.

\subsection{Characterization}

The coatings were characterized using SEM (JSM6360LV) and EDS (GENESIS2000XMS60) in order to investigate their morphologies and chemical compositions.

Five sites were randomly selected on each sample and measured using a roughness tester (TR201). The average value for the five sites was taken to indicate the overall roughness of the coating on the sample. The electrochemical processes during all phases of the composition plating process were monitored using an electrochemical workstation (PARSTAT 2273). The electrode system consisted of a five-inlet vertical electrolytic cell (MZ-1), a Pt electrode, a saturation calomel electrode (218), and a sample holder (Pt-1). The scanning area was $1 \mathrm{~cm}^{2}$, the scanning rate was $0.4 \mathrm{mV} / \mathrm{s}$, and the scanning range was $-1.2 \mathrm{~V}$ to $0.2 \mathrm{~V}$. The deposition rate was defined as the mass increment on unit area in unit time, as follows:

$v=\Delta M /(\Delta t S)$,

where $\Delta M$ is the mass increment $(\mathrm{g}), \Delta t$ is the deposition time (h), and $S$ is the surface area of the sample $\left(\mathrm{m}^{2}\right)$.

\section{MORPHOLOGY AND CHEMICAL COMPOSITION OF COMPOSITE COATINGS}

\subsection{Morphology of SiC/Ni-P nano-composite coating}

Fig. 1 shows SEM images of the different SiC/Ni-P nano-composite coating samples. The images demonstrate that luster of the sample surfaces degraded as the temperature of the water bath furnace decreased. The surface of the coating in Fig. $1 \mathrm{a}$ is consists of a large number of island structures, with large gaps in between. This resulted in high surface roughness, unevenness, and low uniformity and coverage. The coating depicted in Fig. $1 \mathrm{~b}$ has a relatively smooth surface, although several unit cells of $0.70 \mu \mathrm{m}$ can be identified. This structure can be attributed to the relatively high nucleation rate in the deposition process at $85^{\circ} \mathrm{C}$. Fig. $1 \mathrm{c}$ shows unit cells with increased size, while the surface roughness remains low. The main reason for this outcome is that the nucleation rate is low and the deposition product is coarse at lower temperatures. In this case, the sonication-induced cavitation effect and jet flow reported by Luo et al [5] maintained deposition efficiency, while the nucleation rate degraded as the deposition temperature decreased to $75^{\circ} \mathrm{C}$, resulting in increased unit cell size. As the temperature decreased to $65^{\circ} \mathrm{C}, 55^{\circ} \mathrm{C}$, and $45^{\circ} \mathrm{C}$, no coatings were observed in the absence of sonication. Instead, nucleation was observed in the presence of sonication, but the coating mass decreased with the temperature. As shown in Fig. $1 \mathrm{~d}$, e, and $\mathrm{f}$, the inter-cell distance was relatively large, the coating layer was not uniform, and the coating mass decreased significantly. This analysis indicates that the induced sonication exerted an impact on the deposition and morphology of the composite coatings.

\subsection{Chemical composition and phases of $\mathrm{SiC} / \mathrm{Ni}-\mathrm{P}$ nano-composite coating}

Fig. 2 shows the EDS spectra of different SiC/Ni-P nano-composite coating samples. $\mathrm{Ni}, \mathrm{P}, \mathrm{Si}$, and $\mathrm{C}$ were observed on the surfaces of all samples, indicating that a composite coating layer consistently developed. Furthermore, Fe (see Fig. 2 c) arose from the steel substrate, indicating that the composite coating layer was thin. The Fe peaks $(6.4 \mathrm{keV})$ in the EDS spectra in Fig. 2 b, c seem to have higher intensity than that in Fig. 2 a. Low-temperature samples had less coating, which naively led to higher Fe exposure and intensity.
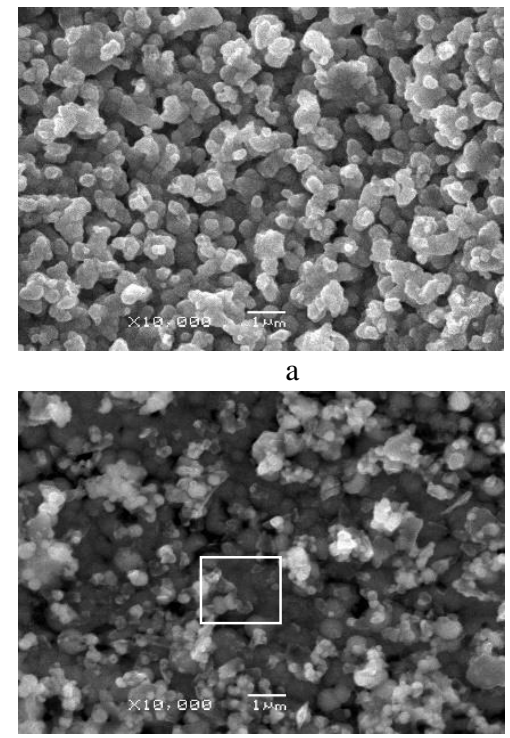

d

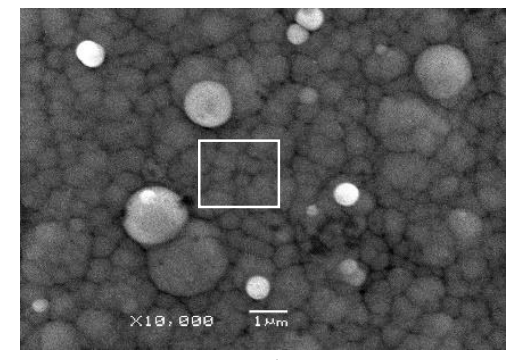

b

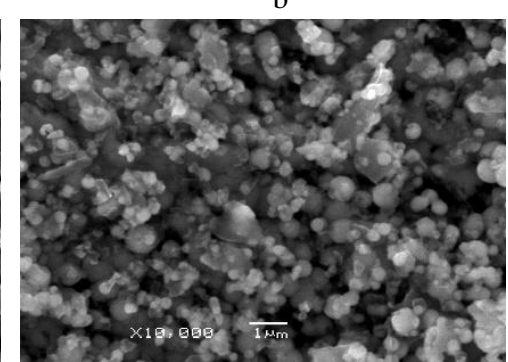

e

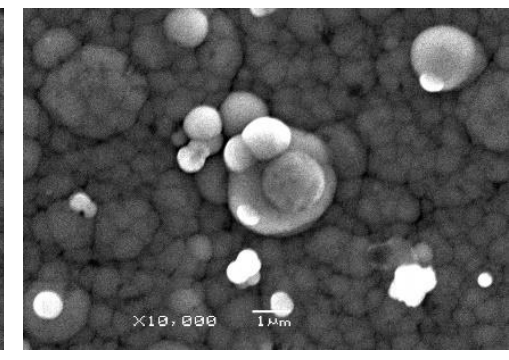

$\mathrm{c}$

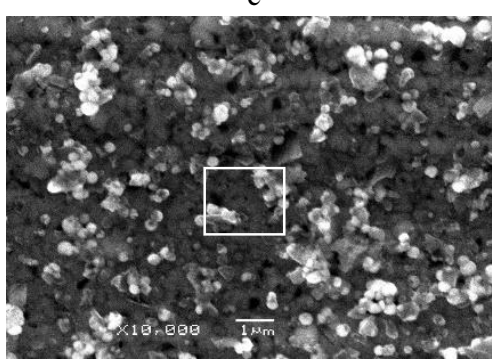

f

Fig. 1. Morphology of different $\mathrm{SiC} / \mathrm{Ni}-\mathrm{P}$ nano-composite coating samples: $\mathrm{a}-85^{\circ} \mathrm{C}$ without sonication-assistant; $\mathrm{b}-85^{\circ} \mathrm{C} ; \mathrm{c}-75^{\circ} \mathrm{C}$; $\mathrm{d}-65^{\circ} \mathrm{C} ; \mathrm{e}-55^{\circ} \mathrm{C} ; \mathrm{f}-45^{\circ} \mathrm{C}$ 


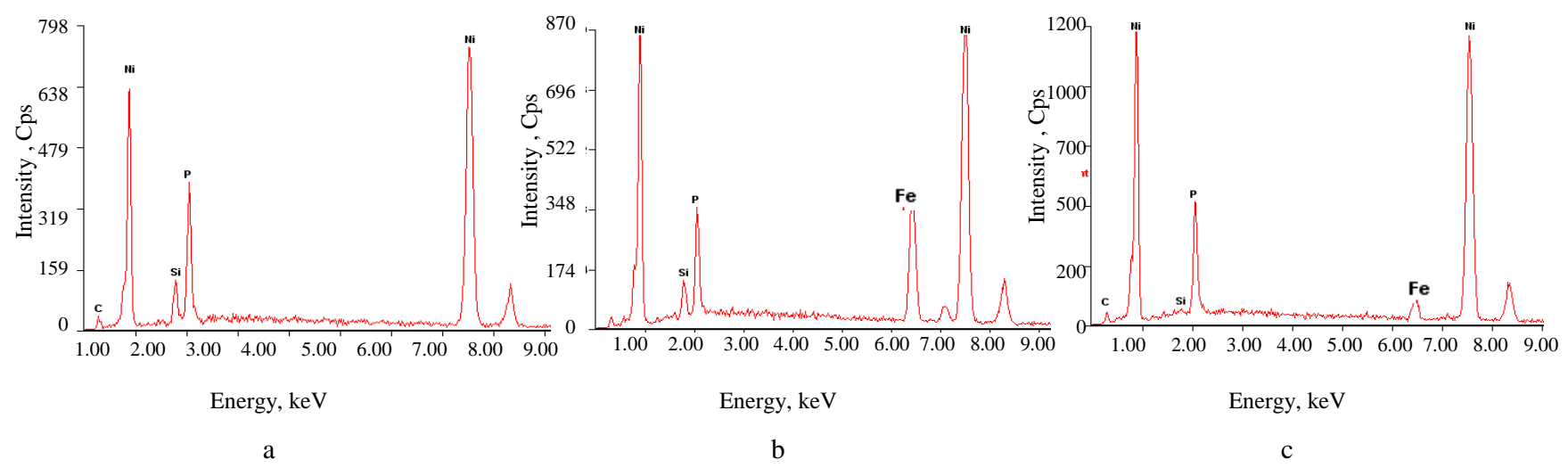

Fig. 2. EDS spectra of different $\mathrm{SiC} / \mathrm{Ni}-\mathrm{P}$ nano-composite coating samples: $\mathrm{a}-85^{\circ} \mathrm{C} ; \mathrm{b}-65{ }^{\circ} \mathrm{C} ; \mathrm{c}-45^{\circ} \mathrm{C}$

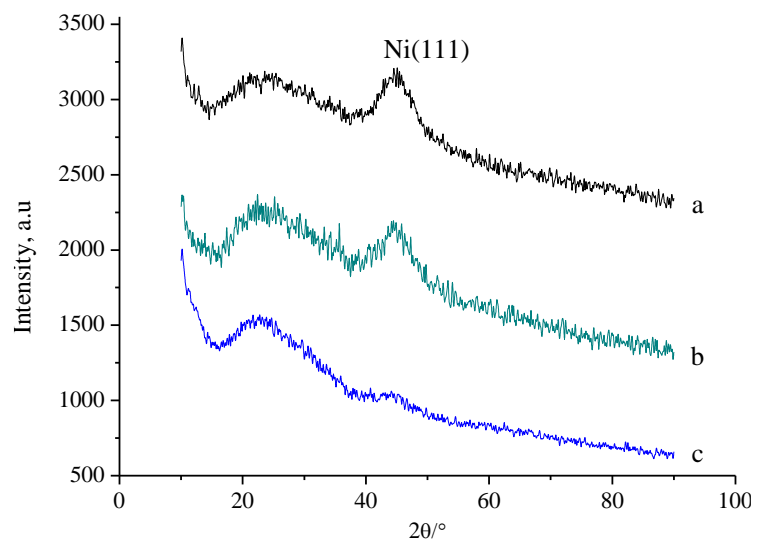

Fig. 3. XRD results of different nano-composite coating samples $\mathrm{a}-85{ }^{\circ} \mathrm{C} ; \mathrm{b}-65{ }^{\circ} \mathrm{C} ; \mathrm{c}-45^{\circ} \mathrm{C}$

Consistent with the SEM images, the EDS spectra indicate that nano-composite coating layers developed during sonication-assisted plating, even at relatively low temperatures.

This result demonstrates the positive effects of sonication on the composite coating deposition process. Fig. 3 provides the XRD spectra of the composite coating samples fabricated at different temperatures. Although the 2 theta angle of $\mathrm{Ni}(111)$ at about 45 degrees manifests a weak diffraction peak in Fig. 3, the XRD results indicate that the coatings are obviously amorphous.

\subsection{Coating layer roughness}

Fig. 4 shows the average surface roughness of different $\mathrm{SiC} / \mathrm{Ni}-\mathrm{P}$ nano-composite coating samples. The surface roughness was observed to increase as the deposition temperature decreased. The surface luster macroscopically diminished, SiC nanoparticles microscopically aggregated, and surface porosity increased. These results are consistent with the SEM images discussed above.

\section{DEPOSITION RATE OF COMPOSITE COATINGS}

\subsection{Polarization curve method}

Zhang et al. [15] obtained the steady state potential and deposition current density of the coating deposition through fitting of the steady state voltage curve $(\varphi$-lgi) of the cathodic polarization curve. Specifically, the Y-axis coordinate of the intersection point is the steady state

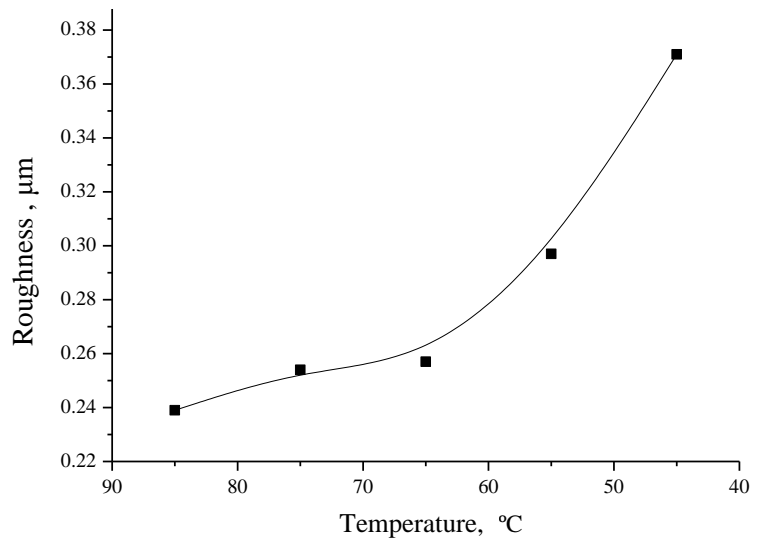

Fig. 4. Surface roughness of different $\mathrm{SiC} / \mathrm{Ni}-\mathrm{P}$ nano-composite coating samples

potential, while $\lg$ (the $\mathrm{X}$-axis coordinate of the intersection point) is the current density required. Based on this foundation, analysis was conducted of the cathodic polarization curves corresponding to composition deposition for different samples. The cathodic polarization curve was represented by semilog $\left(\varphi\right.$-lgi) of $\mathrm{Ni}^{2+}$ in the base solution, as shown in Fig. 5.

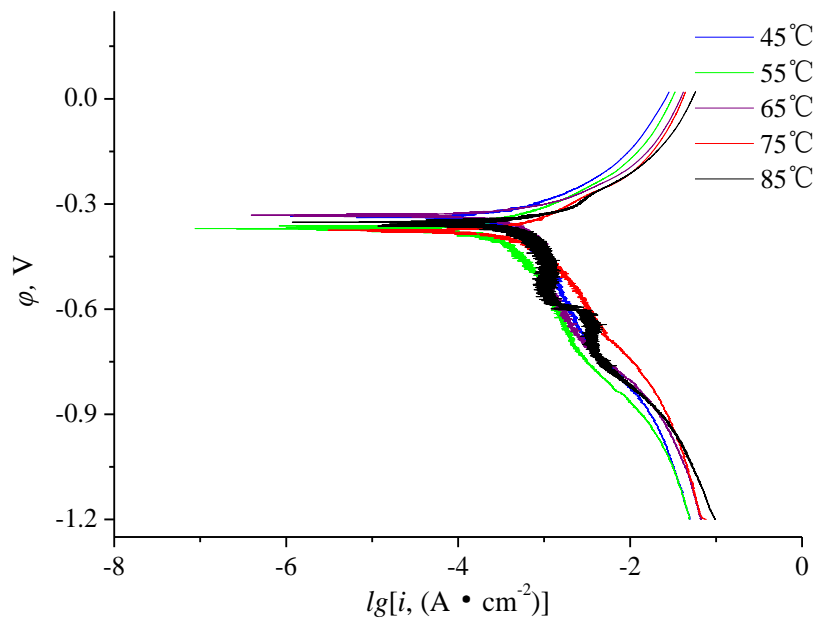

Fig. 5. $\varphi$-lgi curves of the cathodic polarization curves of different samples

A tangential line in the steady area was fitted to obtain steady state potentials and deposition current densities for all samples.

The deposition rates can be calculated by the following equation: 


$$
r=i \times 1.09 \mathrm{~g} /(\mathrm{A} \cdot \mathrm{h})
$$

where $i$ is the deposition current density $\left(\mathrm{mA} / \mathrm{cm}^{2}\right)$ and 1.09 is the electrochemical equivalent of $\mathrm{Ni}$.

Table 2 summarizes the deposition rates of $\mathrm{Ni}^{2+}$ particles in different samples. The data in Table 2 show that the deposition rates of the samples at $85{ }^{\circ} \mathrm{C}$ and $75{ }^{\circ} \mathrm{C}$ were significantly higher than those of the samples at $65^{\circ} \mathrm{C}$, $55^{\circ} \mathrm{C}$, and $45^{\circ} \mathrm{C}$, indicating that the deposition rates of $\mathrm{Ni}^{2+}$ decreased with temperature.

Table 2. Results of electrochemical measurements

\begin{tabular}{|c|c|c|c|c|c|}
\hline $\begin{array}{c}\text { Process } \\
\text { temperature }\end{array}$ & $85^{\circ} \mathrm{C}$ & $75^{\circ} \mathrm{C}$ & $65^{\circ} \mathrm{C}$ & $55^{\circ} \mathrm{C}$ & $45^{\circ} \mathrm{C}$ \\
\hline $\begin{array}{c}\text { Steady state } \\
\text { potential, V }\end{array}$ & 0.3513 & 0.3735 & 0.3292 & 0.3685 & 0.3341 \\
\hline $\begin{array}{c}\text { Deposition } \\
\text { current density, } \\
\mathrm{A} \cdot \mathrm{cm}^{-2}\end{array}$ & 0.5731 & 0.3599 & 0.1421 & 0.1066 & 0.1066 \\
\hline $\begin{array}{c}\text { Deposition } \\
\text { rate, }{\mathrm{mg} \cdot \mathrm{cm}^{-}}^{2 \cdot \mathrm{h}^{-1}}\end{array}$ & 0.625 & 0.385 & 0.155 & 0.116 & 0.116 \\
\hline
\end{tabular}

The non-sonication-assisted depositions were slower, and they approached zero when the temperature was below $65^{\circ} \mathrm{C}$. Sonication had a positive effect on the deposition process, as it produced deposition even at low temperatures. To investigate the effects of sonication, lgi(deposition current density) was plotted against $1 / \mathrm{T}$ for all samples. Yao et al. [16] calculated the apparent Gibbs free energy of deposition reactions $(\Delta G)$ using the following equation:

$\mathrm{d}(\lg i) / \mathrm{d}(1 / \mathrm{T})=-\Delta G /(2.3 R)$,

where $R=8.31 \mathrm{~J} /(\mathrm{mol} \cdot \mathrm{K})$ is a constant.

Fig. 6 shows Arrhenius plots of the different samples.

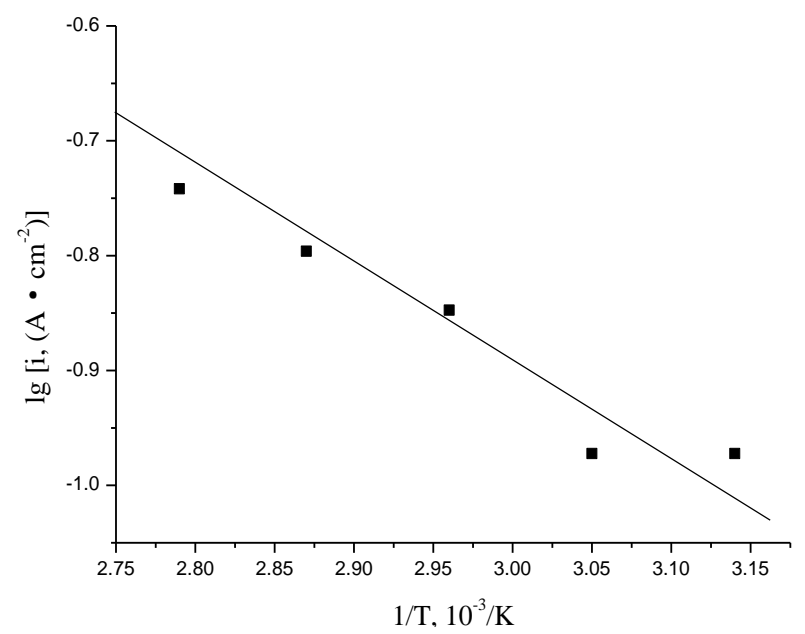

Fig. 6. Arrhenius plots of $\mathrm{SiC} / \mathrm{Ni}$-Pnano-composite electrode

The data indicate that $\Delta G$ of the $\mathrm{SiC} / \mathrm{Ni}-\mathrm{P}$ nanocomposite electrode at $75^{\circ} \mathrm{C}$ through $45^{\circ} \mathrm{C}$ was $16.38 \mathrm{~kJ} / \mathrm{mol}$, while $\Delta G$ of the Ni-P electrode in the absence of sonication was $42.89 \mathrm{~kJ} / \mathrm{mol}$ [17]. This demonstrates that the catalytic effects of sonication degraded as the temperature decreased. However, sonication still produced deposition at low temperatures by enhancing the catalytic activity of Ni-P polarization and hydrogen evolution.

\subsection{Weighing and layer thickness methods}

Fig. 7 summarizes the deposition rates and polarization curves of the different samples. These data were obtained using the weighing method and the layer thickness method. The data indicate that the deposition rates decreased significantly with the temperature, regardless of the calculation method used. Most notably, the deposition rate obtained using the weighing method decreased from $3.9 \mathrm{mg} /\left(\mathrm{cm}^{2} \cdot \mathrm{h}\right)$ to $1.6 \mathrm{mg} /\left(\mathrm{cm}^{2} \cdot \mathrm{h}\right)$. The deposition rate of Sample 5 was negligible, indicating extremely low deposition efficiency at low temperatures.

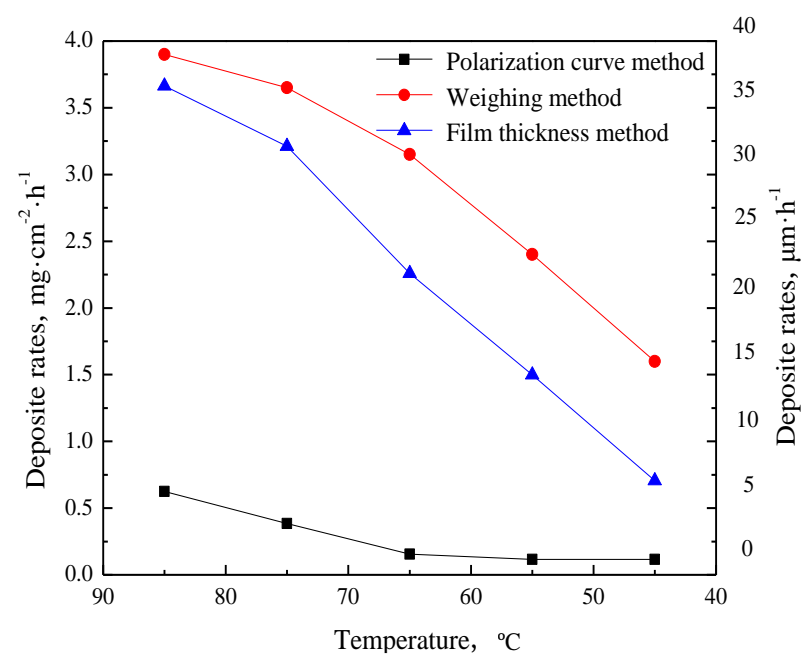

Fig. 7. Deposition rates vs. temperature for different samples

The deposition rate trend identified using the polarization curve method is slightly different from those obtained using the weighing and layer thickness methods. This can be attributed to the fact that the polarization curve method defines the deposition rate in regard to $\mathrm{Ni}$ alone, while the weighing method and the layer thickness method use the overall deposition rate of $\mathrm{SiC}$ nanoparticles, $\mathrm{Ni}$, and P. As shown in Fig. 6, the deposition rate of Ni decreased significantly between $85^{\circ} \mathrm{C}$ and $65^{\circ} \mathrm{C}$, and it remained constant below $65^{\circ} \mathrm{C}$. According to the co-deposition theory of nanoscale electroless composition plating, deposition of $\mathrm{Ni}\left(\mathrm{Ni}^{2+}+2 \mathrm{e} \rightarrow \mathrm{Ni}\right)$ dominates the deposition of composition coating layers, while co-deposition of $\mathrm{SiC}$ nanoparticles results in spherical cell-shaped coating layers.

\section{CONCLUSIONS}

In the presence of sonication (power $1500 \mathrm{~W}$, frequency $20 \mathrm{kHz}$ ), spherical cell-shaped $\mathrm{SiC} / \mathrm{Ni}-\mathrm{P}$ nano-composite coating layers were developed on 45 steel substrates at temperatures between $85^{\circ} \mathrm{C}$ and $45^{\circ} \mathrm{C}$. However, the deposition rates and layer integrity degraded as the temperature decreased. Furthermore, sonication reduced the apparent Gibbs free energy of the deposition reactions while improving the catalytic activity of polarization and hydrogen evolution. In this way, sonication reduced the temperature required for $\mathrm{Ni}-\mathrm{P}$ nano-composite electroless plating and facilitated the deposition of $\mathrm{Ni}$ on the cathode, thus promoting co-deposition of the nano-composite coating layer. 


\section{Acknowledgments}

The work is supported by the National Natural Science Foundation of China (Grant No. 51301088), the Outstanding Scientific and Technological Innovation Team in Colleges and Universities of Jiangsu Province, the innovation practice training projects for the college students of Jiangsu Province (Grant No. 201611276053X), and the innovation practice training projects for the college students of Nanjing Institute of Technology (Grant No. TB20160227, TB201702032).

\section{REFERENCES}

1. Ying, L.X., Liu, Y., Liu, L.Z., Wang, G. Preparation and Properties of Electroless Plating Wear Resistant and Antifriction Composite coatings Ni-P-SiC-WS 2 Rare Metal Materials Engineering 44 (1) 2015: pp. 0028-0031. https://doi.org/10.1016/S1875-5372(15)30006-0

2. Tsai, T.K., Hsueh, S.J., Lee, J.H., Fang, J.S. Optical Properties and Durability of $\mathrm{Al}_{2} \mathrm{O}_{3}-\mathrm{NiP} / \mathrm{Al}$ Solar Absorbers Prepared by Electroless Nickel Composite plating Journal of Electronic Materials 41 (1) 2012: pp. 53-59. https://doi.org/10.1007/s11664-011-1746-2

3. Tu, J.P., Zou, T.Z., Wang, L.Y., Chen, W.X., Xu, Z.D. Friction and Wear Behavior of Ni-based Carbon Nanotubes Composite Coatings Journal of Zhejiang University (Engineering Science) 38 (7) 2004: pp. 931-934. https://doi.org/10.3785/j.issn.1008-973X.2004.07.029

4. Ranganatha, S., Venkatesha, T.V. Studies on The Preparation and Properties of Electroless Ni-W-P Alloy Coatings and Its Nano-MoS 2 Composite Physica Scripta 85 (3) 2012: pp. $3560-3568$. https://doi:10.1088/0031-949/85/03/035601

5. Luo, L.M., Wu, Y.C., Li, J., Zheng, Y. Preparation of Nickel-coated Tungsten Carbide Powders by Room Temperature Ultrasonic-assisted Electroless Plating Surface and Coatings Technology 206 (6) 2011: pp. 1091-1095. https://doi.org/10.1016/j.surfcoat.2011.07.078

6. Lu, Y.X. Improvement of Copper Plating Adhesion on Silane Modified PET Film by Ultrasonic-assisted Electroless Deposition Applied Surface Science 256 (11) 2010: pp. $3554-3558$. https://doi.org/10.1016/j.apsusc.2009.12.153

7. Zhong, L., Hou, L., Liu, C.H., Ying, Q. Study on Process and Performance of Electroless Nickel Plating Nano-C60 Crystals on The Surface of Micromechanical Devices by Laser-induced Way Journal of Synthetic Crystals 40 (6) 2011: pp. $1628-1631$. https://doi.org/10.3969/j.issn.1000-985X.2011.06.051
8. Wang, C., Zhong, Y.B., Jia, J., Ren, Z.M., Ren, W.L., Deng, K. Study on Electro-deposited of Ni-nano- $\mathrm{Al}_{2} \mathrm{O}_{3}$ Composites in 10T Parallel Magnetic Field Functional Materials 38 (S) 2007: pp. 3562-3567.

9. Zhao, G.H., Ren, C., He, Y.D. Ni-P-multiwalled Carbon Nanotubes Composite Coatings Prepared by Mechanical Attrition (MA)-assisted Electroless Plating Surface and Coatings Technology 206 2012: pp. 2774-2779. https://doi.org/10.1016/j.surfcoat.2011.11.033

10. Varsha, R. Activator-assisted Electroless Deposition of Copper Nano-structured Films International Journal of Minerals, Metallurgy and Materials 21 (2) 2014: pp. 196-203. https://doi.org/10.1007/s12613-014-0885-x

11. Vahid, N., Mohammad, G. Mechanical and Electrochemical Properties of Ultrasonic-assisted Electroless Deposition of Ni-

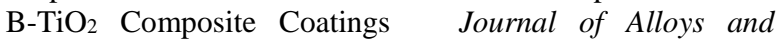
Compounds 633 2015: pp. 127-136. https://doi.org/10.1016/j.jallcom.2015.01.250

12. Zhao, Y.H., Zhang, Z.G., Zhao, Y.Q. Ultrasonic Scattering Technology for Chemical Composite Plating with Ni-P Nano SiC Journal of Lanzhou University of Technology 37 (2) 2011: pp. 26-29. https://doi.org/10.3969/j.issn.1673-5196.2011.02.007

13. Masahiro, O., Yoshiki, T., Takuma, S. Creation of High Strength Bonded Abrasive Wheel with Ultrasonic Aided Composite Plating Surface and Coatings Technology 169 2003: pp. $112-115$. https://doi.org/10.1016/S0257-8972(03)00176-2

14. Campbell, J. Effect of Vibration During Solidification International Metals Reviews 2 1981: pp. 71-104. https://doi.org/10.1179/imtr.1981.26.1.71

15. Zhang, G.D. Study on Reaction Rate and Mechanism of Electroless Ni-P plating Acta Physico-Chimica Sinica 5 1998: pp. $429-434$. https://doi:10.3866/PKU.WHXB19980509

16. Yao, S.W., Yao, Y.W., Zhang, W.G. Study on Hydrogen Evolution Performance of Ni-W/zirconia Nano Composite Electrodes Plating and Finishing 28 (2) 2009: pp. $1-3$. https:// doi:10.19289/j.1004-227x.2009.02.001

17. Xie, Z.H., Yu, G. Kinetics and Mechanism of Acidic Electroless Ni-P Plating Journal of Electrochemistry 20 (6) 2014: pp. 576-581. https://doi:10.13208/j.electrochem.140321 